\title{
Grand Mufti of the Polish Muslims Jakub Szynkiewicz (1884-1966) and his Connections with the Karaites
}

\section{Polonyalı Müslümanların büyük müftüsü Jakub Szynkiewicz (1884-1966) ve Karaimlerle temas}

\author{
Stefan GĄSIOROWSKI ${ }^{1}$
}

${ }^{1}$ Corresponding author/Sorumlu yazar: Stefan Gąsiorowski (Assoc. Prof.),

Jagiellonian University, Cracow, Poland

E-mail: st.gasiorowski@uj.edu.pl

ORCID: 0000-0002-5984-5337

Submitted/Başvuru: 16.08.2021

Revision Requested/Revizyon Talebi:

08.09.2021

Last Revision Received/Son Revizyon:

26.09.2021

Accepted/Kabul: 27.09.2021

Published Online/Online Yayın: 03.12.202

Citation/Atıf: Gasirowski, Stefan. "Grand Mufti of the Polish Muslims Jakub Szynkiewicz (18841966) and his Connections with the Karaites."

Türkiyat Mecmuası-Journal of Turkology 31, 2 (2021): 555-571.

https://doi.org/10.26650/iuturkiyat.983146

\begin{abstract}
Jakub Szynkiewicz lived in a very difficult time and had to make decisions that were oftentimes crucial and motives and effects of which cannot be judged easily. During the Second World War, he was surely faced with hopeless situations when he was responsible for not only himself and his whole family but also the Muslim community the care of which was entrusted to him. For Karaitologists, his relations with the Karaite community are of significance not only during the interwar period but also during the turbulent years of the Second World War. The p eriod between World War I and World War II should be considered as the most important one in his life. Between 1926-1939, Jakub Szynkiewicz, as the Mufti of the Republic of Poland, was the spiritual leader of 19 Muslim communities congregating approx. 6 thousand of the faithful. Thanks to his personal efforts, the Mosque Building Committee in Warsaw was created (1928), the bill on the relationship between the state and the Muslim Religious Association in Poland and its statute were passed (1936), and the First Muslim Congress in Poland was organized (1938). At the same time, he conducted his scientific research, too. It resulted in numerous publications in Polish that popularized knowledge on reach Muslim history and culture in Poland and in the world. He was also very active in the international arena, visiting Muslim communities in Bulgaria, Egypt, Yugoslavia, Palestine, Syria, and Turkey. During those journeys, he tried, among others, to raise funds for the construction of a mosque in Warsaw. His ambitious plans for the development of the Muslim community in Poland were entirely shattered with the outbreak of WWII.
\end{abstract}

Keywords: Jakub Szynkiewicz, mufti, Tatars, Muslim and Karaite communities in Poland, Seraya Shapshal

\section{Öz}

Jakub Szynkiewicz zor günlerde yaşayıp, dürtü ve neticeleri açısından kolayca değerlendirilemeyen önemli kararlar çok sıkça almak zorunda kalmıştı. Her iki Dünya Savaşı sırasında şüphesiz devasız durumlar ile karşılaştı. Zira, sadece kendisi ve ailesinden değil, emanetinde bulunan bütün Müslüman cemaatinden sorumluydu. Karay Türkleri araştıran bilim adamları için, Szynkiewicz'in yalnız iki Dünya Savaşı arasındaki dönemde değil, İkinci Dünya Savaşının çalkantılı yıllarındaki Karay cemaatiyle kurduğu ilişkiler büyük bir önem taşımaktadır. Hayatının en önemli kısmını iki Dünya Savaşı arasındaki dönem oluşturuyordu. 
1926-1939 yılları arasında Jakub Szynkiewicz Polonya Cumhuriyeti müftüsü mevkiinde bulunarak, bünyelerinde yaklaşık 6 bin kişinin bulunduğu 19 Müslüman cemaatinin manevi liderliğini üstlendi. Sayesinde, 1928 yılında Varşova'da Camii İnşaatı Komitesi kuruldu, 1936'da devlet ile Müslüman Din Cemiyeti arasındaki ilişkilere dair bir yasa ve işbu Cemiyetin ana sözleşmesi kabul edilip, 1938 yılında ise Polonya'da ilk Müslüman Kongresi düzenlendi. Bu dönemde yürüttüğü araştırmalarının neticesinde Polonya ve dünyadaki Müslümanların zengin tarihi ile kültürü hakkında birçok bilimsel çalışması Leh dilinde yayımlandı. Uluslararası faaliyetleri çerçevesinde Bulgaristan, Mısır, Yugoslavya, Filistin, Suriye ve Türkiye'deki Müslüman cemaatleri ziyaret etti. Bu seyahatler sırasında birçok etkinliğinin yanı sıra Varşova'daki camiinin inşaatı için para toplamaya çalışıyordu. II. Dünya Savaşı'nın patlamasıyla birlikte Szynkiewicz'in Polonya'daki Müslüman cemaatinin gelişmesiyle ilgili çok geniş kapsamlı planları tamamen yok edildi.

Anahtar kelimeler: Jakub Szynkiewicz, müftü, Tatarlar, Polonya'daki Müslüman ve Karay toplulukları, Seraya Shapshal 


\section{Introduction}

Jakub Szynkiewicz's life and literary output have yet to receive a reliable and scholarly publication. In fact, four articles devoted to him have been published so far. The first one by Artur Pałasiewicz (born in 1951), historian and archivist, was published in 1977 in the Przeglad Orientalistyczny journal (Oriental review; previously Myśl Karaimska, Karaite thought), and it contains an account of the mufti's journey to the Middle East in 1932, which was found in the Central Archives of Modern Records in Warsaw. ${ }^{1}$ The historian provided the account with an introduction that included an outline of J. Szynkiewicz's biography and a description of the Tatars' situation in the Second Polish Republic. The second text regarding the mufti was written by Dr. Ali Miśkiewicz (born in 1945), Polish Tatar, historian and employee of the Institute of History of the Branch of the University of Warsaw in Białystok. It appeared in the first issue of the new journal entitled Życie Muzułmańskie (Muslim life) in 1986. It is actually a three-page-long biographical note on J. Szynkiewicz published on the $20^{\text {th }}$ anniversary of his death. The note does not include any sources or bibliography from which the author has drawn information about the mufti of the Polish Muslims. ${ }^{2}$ The third article, which is also well-known, was written by Dr. Selim Chazbijewicz, (born in 1955), a political scientist, a professor at the University of Warmia and Mazury in Olsztyn and was published in the Przeglad Tatarski journal (Tatar review). ${ }^{3}$ J. Szynkiewicz and his complicated fortune were presented in that work against the background of the history of the Tatars on Polish lands. The fourth text by Dr. Grzegorz Czerwiński, who specialises in the literature of the Polish Tatars after 1918, was delivered as a speech in the 2011 international academic conference entitled Pogranicza, Kresy, Wschód a idee Europy (Frontiers, borderlands, the East and the ideas of Europe) in Białystok and was published two years later. It mainly refers to the mufti's literary activity in the Second Polish Republic. ${ }^{4}$ Additionally, a comprehensive book was brought out in the same year, i.e. 2013. It was prepared by the above-mentioned G. Czerwiński and included accounts of J. Szynkiewicz's numerous journeys. It contains source texts as well as biographical data

1 "Sprawozdanie muftiego Jakuba Szynkiewicza z podróży do Turcji, Syrii, Palestyny i Egiptu w roku 1932 (9 IV - 9 IX)“ [Report by Mufti Jakub Szynkiewicz on his trips to Turkey, Syria, Palestine and Egypt in 1932], prepared for print by Artur Pałasiewicz, Przegląd Orientalistyczny, (1977) issue no. 1, 41-48.

2 Ali Miśkiewicz, "Mufti na Rzeczpospolitą Polską dr Jakub Szynkiewicz. Notka biograficzna w 20 rocznicę śmierci" [Mufti for the Republic of Poland, Dr. Jakub Szynkiewicz. Biographical note on the 20th anniversary of his death], Życie Muzutmańskie, 1 (1407; 1986), 11-13.

3 Selim Chazbijewicz, "Jakub Szynkiewicz postać tragiczna” [Jakub Szynkiewicz a tragic figure], Przegląd Tatarski, (2011) issue no. 2, 8-11.

4 Grzegorz Czerwiński, “O „sprawozdaniach” Jakuba Szynkiewicza, czyli Mufti Drugiej Rzeczpospolitej jako pisarz” [About the ,reports” of Jakub Szynkiewicz, or the Mufti of the Second Republic as a writer], [in:] Pogranicza, Kresy, Wschód a idee Europy [Borderlands, Kresy, the East and the ideas of Europe]. Seria II: Wiktor Choriew in memoriam, scholarly editing by Anna Janicka, Grzegorz Kowalski and Łukasz Zabielski, Białystok 2013 (Colloquia Orientalia Bialostocensia. Literatura, historia; 4). 
about the mufti, discussion and interpretations of his accounts of the journeys. ${ }^{5}$ Moreover, there have been numerous mentions of J. Szynkiewicz in a number of monographs and articles about the Polish Tatars during the interwar period and the Second World War.

\section{Methods}

The article uses a historical methodology based on a critical approach to preserve archival and printed sources as well as literature relating to the discussed subject matter, i.e. research conducted on the basis of heuristic investigations. The work is based mainly on facts about the biography of Jakub Szynkiewicz and his scientific achievements as well as extensive contacts with family members and the Polish Karaite community, with the distinction of dramatic events in which the grand mufti participated during the Second World War.

\section{Results}

J. Szynkiewicz was born on 16 April 1884 in Lachowicze (Lyakhavichy) in the Baranowicze province (in the Minsk Governorate at the time; now in Belarus). Suleiman was his father, and Fatma from the Bohuszewicz family was his mother. J. Szynkiewicz was sent to the first secondary school in Minsk, which is Boys' Realschule, by his parents, and he finished it in 1904. Then, he began studies at Petersburg Institute of Technology from which he moved to the Faculty of Oriental Languages of Saint Petersburg University in 1910. During his studies, J. Szynkiewicz was part of the secret Koło Akademików Muzutmanów Polskich (Circle of Polish Muslim Academicians) that consisted of 12 people and was run by two brothers and law students: Olgierd and Leon Kryczyński. The circle was preoccupied with getting to know the history and culture of the Tatars, cultural and educational activities and raising national consciousness. ${ }^{6}$

After four years of studies, J. Szynkiewicz was forced to stop his studies as the First World War had broken out. He was then called up into the Russian army. He was at the front line until the autumn of 1917. He left for Crimea where his own brother, Mustafa (Maciej) was elected

$5 \quad$ Sprawozdania z podróży muftiego Jakuba Szynkiewicza. Źródła, omówienie, interpretacja [Reports from the journey of Mufti Jakub Szynkiewicz. Sources, overview, interpretation], prepared by Grzegorz Czerwiński, scholarly editing by Jarosław Ławski and Grzegorz Kowalski, Białystok 2013 Książnica Podlaska in. Łukasza Górnickiego, 323, ill. (Colloquia Orientalia Bialostocensia. Literatura, historia; 5).

6 "Szynkiewicz Jakub", [in:] Czy wiesz kto to jest? [Do you know who it is?] [Vol.] 2: Uzupetnienia i sprostowania. Przedruk [Additions and corrections. Reprint], Stanisław Łoza (ed.), Warszawa 1983, 309; Leon Najman Mirza Kryczyński, "Tatarzy polscy a wschód muzułmański” [Polish Tatars and the Muslim East], Rocznik Tatarski, 2 (1935), 76; Miśkiewicz, „Mufti na Rzeczpospolitą” [Mufti for the Republic of Poland], 11; Jacek M. Majchrowski, "Osoby kierujące prawnie uznanymi związkami wyznaniowymi” [Persons managing legally recognized religious associations], [in:] Kto byt kim w Drugiej Rzeczypospolitej [Who was who in the Second Polish Republic], scholarly ed. by J. M. Majchrowski, in cooperation with Grzegorz Mazur and Kamil Stepan, Warszawa 1994, 207; Marek M. Dziekan, "Szynkiewicz Jakub (1884-1966)”, [in:] Pisarze muzułmańscy VII-XX w. [Muslim writers of the 7th-20th centuries], Warszawa 2003, 112; Jan Tyszkiewicz, "Olgierd, Leon i Stanisław Kryczyńscy, działacze kulturalni i badacze przeszłości Tatarów” [Olgierd, Leon and Stanisław Kryczyński, cultural activists and researchers of the Tatars' past], [in:] Leon Najman Mirza Kryczyński lider ruchu społecznego i kulturalnego Tatarów Polskich [Leon Najman Mirza Kryczyński leader of the social and cultural movement of the Polish Tatars], Selim Chazbijewicz (ed.), Gdańsk-Gdynia 1998, 23. 
as the leader of the Society of the Lithuanian Tatars in Simferopol in 1918. J. Szynkiewicz stayed there until 1919. After he arrived in Poland in 1920, he was awarded a government scholarship to continue his oriental studies at the University of Berlin. Besides studying oriental languages, he also attended lectures on philosophy and history. There in 1925, he defended his doctoral dissertation entitled Rabghûzîs Syntax that was on syntax and word order in the Old Anatolian Turkish. It was published a year later. ${ }^{7}$

On 28-29 December 1925, I Wszechpolski Zjazd Delegatów Gmin Muzułmańskich (First All-Polish Congress of Delegates of Muslim Communities) was held in Wilno. 58 delegates from 18 communities participated in it and deliberated in the presence of voivode Olgierd Malinowski, the representative of the Ministry of Foreign Affairs Dr. Jan Grzymała-Grabowiecki, the mayor of the city of Wilno Witold Bańkowski and the rector of Stefan Batory University Professor Marian Zdziechowski. The delegates, who accepted the rule of autocephaly of the followers of Islam in Poland, elected J. Szynkiewicz in absentia as the lifelong mufti of the Polish Republic and Colonel Jakub Romanowicz his deputy. At the same time, a commission was appointed, which was to prepare a bill regarding the relationship between the state and Muzutmański Zwiazek Religijny w Polsce (the Muslim Religious Association in Poland) and the articles of the association.

J. Szynkiewicz returned to the country in January of the following year and took care of approximately 6,000 believers who lived in 19 Muslim communities in Vilnus (Wilno), Niemież, Sorok Tatary, Dowbuciszki, Widze, Dokszyce and Miadziole in the Vilnius Voivodeship; Navahrudak (Nowogródek), Łowczyce, Słonim, Lachowicze, Murawszczyzna, Niekraszuńce, Kleck, Osmołowo and Mir in the Navahrudak Voivodeship; Kruszyniany and Bohoniki in the Białystok Voivodeship, and Warsaw. Wilno was the seat of the muftiate, which consisted of the mufti, a secretary, typist and an usher. The office was initially located at 5 Zaułek Św. Michalski (Saint Michalski Alley) and later from 1937 at 7 ulica Ostrobramska (Ostrobramska Street). ${ }^{8}$

The mufti's responsibilities included first and foremost: representing the Muslim Religious Association before the state authorities of the Polish Republic ${ }^{9}$ and clergymen of other religions, supervision of Muslim clerics (18 imams and 12 muezzins who were chosen by the believers and confirmed by the mufti), 16 mosques (17 since 1934), religious teaching and activities of each

7 Jakob Schinkewitsch, Rabghûzîs Syntax. Inaugural-Dissertation zur Erlangung der Doktorwürde genemigt von der Philosophischen Fakultat der Friedrich-Wilhelm-Universitat zu Berlin. Tag der Promotion: Berlin 10. Juni 1926, 47; Miśkiewicz, "Mufti na Rzeczpospolitą", 11-12; Chazbijewicz, Jakub Szynkiewicz, 9-10.

8 "Kronika" [Chronicle], Rocznik Tatarski, 1 (1932), 321-322; Kryczyński, Tatarzy polscy, 98; Piotr Borawski, "Tatarzy w dawnej Rzeczypospolitej" [Tatars in the former Polish-Lithuanian Commonwealth], Warszawa 1986, 297; Leon Bohdanowicz, Selim Chazbijewicz, Jan Tyszkiewicz, "Tatarzy muzułmanie w Polsce” [Muslim Tatars in Poland], Gdańsk 1997, 44-45; Joanna Januszewska-Jurkiewicz, Stosunki narodowościowe na Wileńszczyźnie w latach 1920-1939 [National relations in the Vilnius Region in the years 1920-1939], $2^{\text {nd }}$ edition, Katowice 2011, 650 .

9 On 22 September 1929 J. Szynkiewicz hosted President of Poland Ignacy Mościcki in the mosque in Nowogródek, in his presence he gave a speech and held a service for the prosperity of Poland and the president. "Kronika", Rocznik Tatarski, 1 (1932), 320-321. 
community, settling issues regarding Islam with regards to Islamic teachings, interpretations of the Quran, sharia law and all religious practices.

In Vilnius on 27 December 1931, I Wszechpolska Konferencja Prawników Muzułmanów (the First All-Polish Conference of Muslim Lawyers) was held, and they deliberated the bill regarding the relationship between the state and the Muslim Religious Association in Poland and its articles. It was decided that the term of office for a mufti would be 7 years and the need for the creation of Najwyższe Kolegium Muzutmańskie (the Highest Muslim Council) was decided by voting. The above-mentioned bill was submitted by the president of the Muslim law commission, Aleksander Achmatowicz, the minister of Ministry of Religious Affairs and Public Education Janusz Jędrzejewicz on 18, January 1932. The content of the bill on the relationship between the state and the Muslim Religious Association in Poland and the articles of the association were finalised at the conference of Director of the Religious Affairs Department in the Ministry of Religious Affairs and Public Education, Count Franciszek Potocki with J. Szynkiewicz on 3 December 1934. The act was passed by the Sejm of the Republic of Poland on 21 April 1936 (published in the Journal of Laws of the Republic of Poland, Dziennik Ustaw, on 24 April 1936). The act on the relationship between the state and the Karaite Religious Association in Poland (Karaimski Zwiazek Religijny w Polsce) was passed on that very day as well. At 11 o'clock on 26 April of that year in the great conference room of the voivode's offices in Wilno, in the presence of numerous guests, Minister of Religious Denominations and Public Enlightenment Wojciech Świętosławski presented copies of the Journal of Laws of the Republic of Poland with the articles of their Religious Associations to mufti J. Szynkiewicz and Seraya Shapshal (Pol. Seraj Szapszał), khan of the Karaites of the Republic of Poland. They were also awarded the Commander's Crosses with Star of the Order of Rebirth of Poland (Krzyż Komandorski z Gwiazda Orderu Odrodzenia Polski) by President of the Republic of Poland Ignacy Mościcki upon request of Prime Minister Marian Zyndram-Kościałkowski for efficient organisation of the Muslim and Karaite communities in Poland.

While presenting the functions held by J. Szynkiewicz in the Second Republic of Poland, it must be added that he became the first leader of the Highest Muslim Council upon its establishment by Pierwszy Kongres Muzulmański (First Muslim Congress) on 31 January 1938 in Wilno. ${ }^{10}$

On 3 April 1928 the Mosque Building Committee (Komitet Budowy Meczetu) was formed in Warsaw, and J. Szynkiewicz was its honorary member. For this purpose, the city authorities

10 "Kronika”, Rocznik Tatarski, 1 (1932), 322-323; "Kronika”, Rocznik Tatarski, 2 (1935), 478; Miśkiewicz, "Mufti na Rzeczpospolitą", 12; Borawski, "Tatarzy w dawnej Rzeczypospolitej”, 297-298; Januszewska-Jurkiewicz, Stosunki narodowościowe, 650-651; Chazbijewicz, “Jakub Szynkiewicz”, 10; Zarządzenie 179. Dziennik Ustaw RP z 24 kwietnia 1936 r. M.P. 1936 nr 97 poz. 179 (Directive no. 179. the Journal of Laws of the Republic of Poland from 24 April 1936 Monitor Polski 1936 item no. 179); March 20, 2021. isap.sejm.gov.pl; Janusz Fałowski, "Uwagi o sytuacji prawnej Karaimskiego Związku Religijnego w II Rzeczypospolitej” [Comments on the legal situation of the Karaim Religious Association in the Second Polish Republic], [in:] Między Wschodem a Zachodem [Between East and West], Piotr Stawiński (ed.), Częstochowa 1995, 41-43; "Uroczystość wręczenia odznaczeń najwyższym duchownym: karaimskiemu i muzułmańskiemu" [The ceremony of awarding decorations to the highest clergy: Karaim and Muslim], Myśl Karaimska, 11 (1935-1936) fascicule no. 11 [print:] 1936, 123-125. 
transferred the empty square in ulica Krzyckiego (Krzyckiego Street) free of charge only in April 1934. Following that event, the Presidium of the Committee, with president Abdul Hamid Churamowicz and the mufti at its head, appealed to the Polish Muslims for help in building the mosque. The competition for its architectural design was concluded in March 1936. The Committee, in agreement with J. Szynkiewicz, approved Stanisław Kolendo and Tadeusz Tołwiński’s design. Unfortunately, government grants for the Muslim Religious Association were insufficient, and funds from abroad were not obtained despite the mufti's strenuous efforts. The outbreak of the Second World War ultimately shattered hopes of erecting a Warsaw mosque. ${ }^{11}$

The new mufti of the Republic of Poland was on the move since the very beginning of his activity. He was on a journey to Egypt from April to June in 1926. He participated in the AllMuslim Congress in Cairo on 13-19 May. The Congress convened to discuss the issue of the resurrection of the caliphate. From August to October in 1928, he visited Yugoslavia, Bulgaria, and Turkey in order to establish relationships with Muslims there. Yet, from March to July 1930, he was again on a trip to the Middle East. During that visit, the mufti visited Egypt, the Kingdom of Hejaz (present-day Saudi Arabia), Palestine, and Syria. In Cairo, J. Szynkiewicz was received by King Fuad I (1868-1936), who gave 500 pounds sterling for the restoration of mosques in Poland. He went on a trip to Hejaz as a member of the Polish diplomatic delegation together with Edward Raczyński, Deputy Chief of the Oriental Department of the Ministry of Foreign Affairs the task of which was to establish relationships between Poland and Ibn-Saud ${ }^{12}$, King of Hejaz, Najd and other countries. They had an audience with the King on 3 and 4 May during which the mufti made him a gift of an $18^{\text {th }}$-century Quran manuscript of Polish origin and an album with photographs of Polish mosques. Next, Szynkiewicz went on a pilgrimage to Mecca and Medina. On his way back to Poland, the mufti visited Palestine and Syria, as mentioned above. In October and November of the same year, J. Szynkiewicz, as a representative of Polish Muslims, took part in the celebrations connected with the inauguration of Hafiz Ibrahim efendi Maglajlicz's hajj. Hafiz Ibrahim efendi Maglajlicz was a newly appointed reis-ul ulema, i.e. head of the Muslim religion in Yugoslavia. The inauguration took place in Belgrade on 31 October 1930 in the presence of King Alexander I, who gave the mufti the $3^{\text {rd }}$ Class Order of the White Eagle. The mufti's next journey to the Middle East, which lasted from 9 April to 9 September in 1931, had a practical purpose, i.e. obtaining a number of religious books which could enable a revival of Muslim religious life in Poland and eliminate any error in the ritual. J. Szynkiewicz visited Egypt where he was again received by King Faud I and was able to thank him for the financial support in the restoration of 16 Polish mosques and 2 houses of prayer. Later, he visited Syria, Palestine, Turkey, Bulgaria, and Romania. It should be noted that the mufti attended the World Muslim Congress in Jerusalem during that journey, and he said that Jews had the right to create

11 Arkadiusz Kołodziejczyk, "Komitet Budowy Meczetu w Warszawie" [Mosque Building Committee in Warsaw], Życie Muzutmańskie, 2 (1407/1408; 1987), no. 2-4, 45, 47-49.

12 Abd al-Aziz ibn Abd ar-Rahman ibn Fajsal Al Su'ud, called Ibn Saud (1880-1953), united independent kingdoms of the Arabian Peninsula and created the Kingdom of Saudi Arabia. 
their own state in Palestine in an interview he gave to one of local newspapers. On 20 and 21 October 1934 he went to Geneva, Paris, and Berlin on matters of the Muslim community. Then on 12-15 May 1935, J. Szynkiewicz was present at the European Muslim Congress in Geneva. Finally, he went to East India (present-day Pakistan) in 1937 to visit Muslim population centres and collect money for the building of the mosque in Warsaw (in his publication from 1997, S. Chazbijewicz claims that the mufti did not go to India because the Second World War broke out). He was received at the main office of the Ahmadiyya Muslim Community in Qadian by Caliph Mirza Basheer-ud-Din Mahmood Ahmad, who was to grant a sum for the building of the mosque in the capital of Poland. ${ }^{13}$

It is significant that J. Szynkiewicz left comprehensive records of all his journeys, the fragments of which he published in Życie Tatarskie (Tatar life) during his lifetime. As already mentioned, after his death, in 1977 an account of his 1932 journey appeared in Przeglad Orientalistyczny (Oriental review), and later in 2013, all his preserved accounts appeared in a separate publication prepared by G. Czerwiński. ${ }^{14}$

J. Szynkiewicz was concerned with good education of the Muslim youth and in particular with their conversance with oriental languages and Islam. Thus, he fought for numerous government scholarships and help from various institutions and people for talented students of Tatar origin. For instance, in 1927, he asked Professor Tadeusz Kowalski for help in finding resources for a Tatar acquaintance of his, Ibrahim Szegidewicz, who wanted to study the Arabic and Turkish language at the Jagiellonian University after his matriculation but lacked adequate resources. In 1933, he procured scholarships for Mustafa Aleksandrowicz and Ali Ismail Woronowicz's complementary studies at Al-Azhar University in Cairo (they were graduates of the Institute of Oriental Studies of Jan Kazimierz University in Lviv), thanks to the support of Rada Centralna Związu Kulturalno-Oświatowego Tatarów (Central Council of the Educational and Cultural Association of the Tatars), the Polish Ministry of Foreign Affairs, and the Oriental Institute in Warsaw. Moreover, he sent the Eskanowy brothers from Warsaw, Samuel Assanowicz from Nowogródek and Jusuf Konopacki from Sokółka to a Muslim secondary school Gazi Husrev-bey Medresa in Sarajevo. ${ }^{15}$

13 "Kronika”, Rocznik Tatarski, 1 (1932), 323-324; Kryczyński, "Tatarzy polscy", 101-103, 113; "Kronika”, Rocznik Tatarski, 2 (1935), 467, 477; Miśkiewicz, "Mufti na Rzeczpospolitą", 12; Dziekan, "Szynkiewicz Jakub”, 112; Bohdanowicz, Chazbijewicz, Tyszkiewicz, Tatarzy muzułmanie, 78; "Euroislam”, Dawid Warszawski's interview with Selim Chazbijewicz, Gazeta Wyborcza, July 16, 2004; March 20, 2021 www.ipdirect.home.pl/kmp/kiosk/ Polscy_muzulmanie/euroislam_selim_chazbijewicz.htm; www.alislam.pl.

14 "Sprawozdanie muftiego Jakuba Szynkiewicza z podróży do Turcji, Syrii, Palestyny i Egiptu w roku 1932 (9 IV - 9 IX)", prepared for print by A. Pałasiewicz, Przeglad Orientalistyczny, (1977) issue no.1; Sprawozdania z podróży muftiego Jakuba Szynkiewicza. Źródła, omówienie, interpretacja, prepared by G. Czerwiński, Białystok 2013.

15 J. Szynkiewicz's letter to T. Kowalskiego of 4 June 1927, Archive of Science PAN\&PAU in Cracow. Zespół Tadeusz Kowalski, catalogue no. K III - 4, 175, leaf no. 3; "Kronika", Rocznik Tatarski, 2 (1935), 468, 471, 484; Miśkiewicz, "Mufti na Rzeczpospolitą", 12-13. 
Apart from his numerous official duties, J. Szynkiewicz was also engaged in academic work. Besides publishing his accounts of foreign journeys and a practical handbook of the Arabic language by Ali Smajkiewicz, he translated fragments of the Quran regarding social science and Islamic ethics into the Polish language, which were published under the title Wersety z Koranu (Verses from the Quran, Sarajevo 1935). In addition to those, he wrote articles on the history and culture of the Polish-Lithuanian Tatars. Two texts among them should be mentioned: "O kitabie" (On kitab), which describes a religious book from 1792 found in the mosque in Kruszyniany and "Literatura religijna Tatarów litewskich i jej pochodzenie" (Religious literature of the Lithuanian Tatars and its origin). These works were printed in two volumes of Rocznik Tatarski (Tatar yearbook). ${ }^{16}$ Moreover, a short dictionary of Tatar first names and proper names with Polish translation by J. Szynkiewicz appeared in Herbarz rodzin tatarskich $w$ Polsce (Armorial of Tatar families in Poland) by Stanisław Dziadulewicz (Wilno 1929). ${ }^{17}$ The mufti published popular articles as well, e.g. "Tolerancja w islamie" (Tolerance in Islam) in the December issue of Życie Tatarskie. He also issued Muslim calendars for each year (e.g 1934). ${ }^{18}$

Zwiazek Kulturalno-Oświatowy Tatarów Rzeczypospolitej Polskiej (Cultural and Educational Association of the Tatars of the Republic of Poland) was established in 1926. J. Szynkiewicz would give papers in its Wilno branch. For example, in 1926, he presented the following papers: "Sprawozdanie z Kongresu Muzułmanów w Kairze" (Minutes from the Muslim Congress in Cairo, 26 November) and "Pogadanki religijne" (Religious talks, 18 December); in 1928: "Wrażenia z podróży do Turcji i Jugosławii” (Impressions from the journey to Turkey and Yugoslavia, 4 December); in 1933: "Podróż do Syrii” (Journey to Syria, 4 November); and in 1934: "Podróż do Palestyny" (Journey to Palestine, 21 January). Seraya Shapshal, the khan of the Karaites of the Republic of Poland, also participated in the above meetings and delivered a paper "Kiedy i wskutek czego Tatarzy w Polsce utracili mowę ojczysta" (Why and as a result of what did the Tatars in Poland lose their native language) on 11 December $1932 .{ }^{19}$ This text was subsequently published in the first volume of Rocznik Tatarski. ${ }^{20} \mathrm{~J}$. Szynkiewicz polemicized with this article. The mufti disagreed with the khan's conclusion that the Lithuanian Tatars had lost their primary language solely because of their interfaith marriages to Christian women.

16 Jakób Szynkiewicz, “O kitabie” [About kitaba], Rocznik Tatarski, 1 (1932), pp. 188-194; Szynkiewicz, "Literatura religijna Tatarów litewskich i jej pochodzenie" [Religious literature of Lithuanian Tatars and its origin], Rocznik Tatarski, 2 (1935), 138-145; Miśkiewicz, "Mufti na Rzeczpospolitą", p. 13; Bohdanowicz, Chazbijewicz, Tyszkiewicz, Tatarzy muzulmanie, 72.

17 J. Szynkiewicz, "Tłumaczenia słów i nazw orientalistycznych" [Translations of oriental words and names], [in:] Stanisław Dziadulewicz, Herbarz rodzin tatarskich $w$ Polsce [Herbarium of the Tatar families in Poland], Wilno 1929, 457-473.

18 "Kronika", Rocznik Tatarski, 2 (1935), 479.

19 "Kronika", Rocznik Tatarski, 1 (1932), 329-331; "Kronika”, Rocznik Tatarski, 2 (1935), 470, 473; "Kronika”, Ateneum Wileńskie, 10 (1935), 569.

20 Seraja Hadży Szapszał (Seraya Hajji Shapshal), "O zatraceniu języka ojczystego przez Tatarów w Polsce” [About the loss of the mother tongue by the Tatars in Poland], Rocznik Tatarski, 1 (1932), 34-48. 
According to the former, the reason for such a state of affairs was most likely the fact that Tatars were scattered around different settlements in Poland and Lithuania. He also claimed that interfaith marriages were fairly rare for the Crimean Tatars who came to Lithuania with their whole families already in the Middle Ages when they were running from the fratricidal wars which raged in the Golden Horde. ${ }^{21}$

Despite their differences in opinions on scholarly matters, J. Szynkiewicz and S. Shapshal had a lot in common. They both studied at the Department of Oriental Languages of Petersburg University and served in the Russian army. They also had many ties with Crimea which will be described below. They published in the same periodicals and were members of Polskie Towarzystwo Orientalistyczne (Polish Oriental Society). It is also noteworthy that the leader of the Karaites of the Republic of Poland conducted Turkish language classes at Instytut Naukowy Badań Europy Wschodniej (Scientific Institute of Research on Eastern Europe) in Wilno from December 1930. He published Wypisy tureckie (Turkish extracts, Wilno 1931) and Słownik turecko-polski (Turkish-Polish dictionary, Wilno 1932) for his students. Moreover, the khan had J. Szynkiewicz's surname and address in Vilnius noted down in his 1939 pocket diary. ${ }^{22}$ Interestingly, the Tatar cemetery in Vilnius was and still is located on the outskirts of the city and near the Karaite necropolis. Both were established at the end of the $19^{\text {th }}$ century in Lipowa Street (Pol. ul. Lipowa, now Žirniu gatve). ${ }^{23}$

The mufti took part in many official events connected with the Muslim community in Poland and abroad, meetings with government officials, clergymen and foreign visitors. In 1928, the King of Afghanistan, Amanullah Khan (1892-1960) visited Poland. On 20 April of that year the President of the Republic of Poland I. Mościcki gave a reception in his honour in the Royal Castle in Warsaw. Numerous guests were present, and J. Szynkiewicz gave a welcome speech to the king. On 1 May, the mufti and other members of the Polish Tatar delegation were received at the audience with Amunullah Khan in the Palace of the Cabinet of Poland. Then in June 1930, Turkish Member of Parliament, Reşit Saffet (Atabinen) Bey, political scientist, close associate of Gazi Mustafa Kemal and Chief Editor of L'Économiste d'Orient arrived in Poland. He visited Wilno and the Wilno region and was accompanied by J. Szynkiewicz. On 27 July, the khan S. Shapshal guided the Turkish parliamentarian and the Polish government delegation round Troki. In 1934, J. Szynkiewicz participated in a meeting with the leader of Yugoslavia’s Muslims, Smail-aga Čemalovič. In the same year, two momentous events took

21 Jan Stankiewicz, "Belaruskija musulmanie i belaruskaja literatura arabskim pismom", Hadawik Belaruskaga nawukowaga tawarystwa u Wilni, 1 (1933), 111-141; Reviewed by J. Szynkiewicz, Rocznik Tatarski, 2 (1935), 454-455.

221939 Calendar in the Library of the Lithuanian Academy of Sciences in Vilnius. Manuscripts Catalogue, catalogue no. F. 143-79; "Kronika”, Rocznik Tatarski, V1 (1932), 329-331; "Kronika”, Rocznik Tatarski, 2 (1935), 466; S. Gąsiorowski, "Szapszał Seraja Markowicz (1873-1961)”, [in:] Polski Słownik Biograficzny [Polish Biographical Dictionary], Vol. 47, Warszawa-Kraków 2010, fascicle no. 192, 61-64.

23 Emanuel Włodzimierz Łopatto, Byle na Zachód [Anywhere to the West], conversations with Wiesław Mincer, Warszawa 2001, 99; Grzegorz Rąkowski, Ilustrowany przewodnik po zabytkach kultury na Litwie [Illustrated guide to cultural monuments in Lithuania], Warszawa 1999, 408. 
place in the presence of the mufti. The first one was the opening of a new mosque in Widze (brasławski district) on 15 June; it was raised in place of the previous one which was burnt down during the First World War. Yet, on 20 June, a marble plaque in honour of Countess Elfryda Augustowa Zamoyska was unveiled on a wall in a mosque in Murawszczyzna (lidzki district). She was the benefactress of this house of prayer 50 years prior to the event. On 23 April 1935, J. Szynkiewicz attended a reception given by the President of the Republic of Poland, I. Mościcki on the occasion of signing the new constitution in the Royal Castle in Warsaw. On 17 May of the same year, in Warsaw he and other dignitaries, including representative of the Karaites ułłu hazzan Szymon Firkowicz delegated by the khan S. Shapshal - he and J. Szynkiewicz walked side by side, were present at a funeral service connected with the funeral of Marshal Józef Piłsudski. ${ }^{24}$

\section{Discussion}

Before describing facts from J. Szynkiewicz's life and activities during the Second World War, some family connections that are particularly significant in this context must be presented. On 16 October 1927, the mufti entered into a marriage with a Tatar woman, Lidia Talkowska (10 July 1910 - 15 February 1982). In 1939, she started Koło Pań Tatarek Polskich (Circle of Polish Tatar Ladies). The wife bore him a son, Dżemil (Jamil) (15 December 1928 - 4 July 2011?). ${ }^{25}$ As mentioned above, J. Szynkiewicz also had a brother, Mustafa in Crimea, who was unable to return to Poland after the Bolsheviks took control over the peninsula in 1920. In 1928, he and his son, Edige (Mustafa Kyrymał Szynkiewicz; 1911-1980) were arrested by the Soviet authorities on suspicion of propagating Tatar nationalism, Trotskyism and spying for the benefit of the White Guard organisations. They were sent to a gulag in the Arctic Circle. The mufti's brother died shortly, and his son escaped from exile in the summer of 1932 and reached Persia through Baku. In Tehran, he received help from the Polish Embassy, thanks to which he came to J. Szynkiewicz, his uncle, in Wilno through Turkey and Romania in 1933. Mufti took care of his nephew and even made a written request to Professor Tadeusz Kowalski to enable him to study Turkology at the Jagiellonian University. However, he did not go ahead with the plan, most probably for financial reasons. Edige Szynkiewicz stayed in Wilno and got engaged in the activities of Zwiąek Kulturalno-Oświatowy Tatarów w Polsce (Cultural and Educational Association of the Tatars in Poland). He presented papers on the situation of the Tatars in Crimea and the USRR at the meetings of that association in Wilno, Słonim, and Warsaw. In 1935, he joined the board of the Muslim community in Wilno and became the president of the newly formed Koło Młodzieży Tatarskiej (Circle of the Tatar Youth) of

24 Kryczyński, Tatarzy polscy, 106-108, 113, 122-123; “Kronika”, Rocznik Tatarski, 2 (1935), 475, 476, 481, 482; Szymon Firkowicz, "Przyjazd Reszyd Saffet Beja" [Arrival of Reşit Saffet Bey], Myśl Karaimska, 2 (1931), fascicle no. 3/4, 75-77; “Z życia Karaimów w Polsce” [From the life of Karaims in Poland], Myśl Karaimska, 11 (1935-1936), fascicle no. 11 [printed:] 1936, 114, 117 (photographies).

25 “Szynkiewicz Jakub”, [in:] Czy wiesz kto, 309; Miśkiewicz, "Mufti na Rzeczpospolitą", 13. 
Związek Kulturalno-Oświatowy Tatarów. Selim Chazbijewicz presumes that already at that time Edige started cooperation with the Turkish and German intelligence; yet, he provides no evidence to support his theory. After the Second World War broke out, Edige left Poland and went to Turkey. In the period 1941-1942, he started talking to the German authorities in Berlin by the agency of Franz von Pappen, the ambassador of the Third Reich in Ankara, about organising Tatar volunteer units within the German armed forces (Wehrmacht) consisting of Russian prisoners of war of Tatar origin. Nonetheless, Edige's collaboration with the Germans and activities in Crimea did not bring about the creation of a Tatar state there. ${ }^{26}$

According to Selim Chazbijewicz, J. Szynkiewicz was inspired by his nephew's activities and also started cooperating with the Germans. Presumably, already during his studies in Berlin, young J. Szynkiewicz struck up an acquaintance with a student of philosophy, Joseph Goebbels, Reich Minister of Propaganda during the Second World War. This fact has significance in the context of his subsequent relations with Karaites. Yet, these pieces of information raise considerable doubts as Goebbels studied literature and philosophy between 1917-1921 at the universities in Bonn, Würzburg, Freiburg, and Heidelberg, not Berlin. He completed his education with a doctorate degree earned at Heidelberg University. He arrived in Berlin in October 1926 when he became a gauleiter there (a district leader of the NSDAP party). ${ }^{27}$ As we know, J. Szynkiewicz completed his studies in Berlin in 1925, that is before Goebbels arrived in the city. Nevertheless, S. Chazbijewicz states that Goebbels remembered his old acquaintance during the Second World War and contributed J. Szynkiewicz's appointment as the German mufti of Ostland, i.e. Poland, Belarus, Lithuania and other Baltic states under German occupation. J. Szynkiewicz was then subordinate to the grand mufti of Jerusalem, Amin al-Husseini (whom Heinrich Himmler appointed SS Obergruppenführer as the nominal head of the Arab Legion of the Waffen SS), who was appointed chief of all Muslims in the areas under the rule of the Third Reich by the German authorities. From the beginning of 1942, J. Szynkiewicz made endeavours at the German authorities towards the appointment of Tatar committees in Belarus. He established his agency in Minsk in the autumn of 1942. In March 1944, Zwiazek Młodzieży Tatarskiej (Association of the Tatar Youth) was established on his initiative, which was modelled on the Hitlerjugend organisation, but did not branch out. ${ }^{28}$

According to Selim Chazbijewicz, J. Szynkiewicz saved Wilno Karaites from German extermination. The information on this subject was imparted by a known political scientist in a few of his publications from 1995 to 2011. Supposedly, the episode took place in 1943 when the fate of the Lithuanian Karaites was being decided. J. Szynkiewicz was to call Joseph

26 J. Szynkiewicz's letter to T. Kowalski of 23 November 1933. Archive of Science PAN\&PAU in Cracow, catalogue no. K III-4, 175, leaf no. 6-6v; "Kronika”, Rocznik Tatarski, 2 (1935), 471, 476, 480; Chazbijewicz, "Jakub Szynkiewicz", 10.

27 Ralf Georg Reuth, Goebbels, translated by Michał Misiorny, Warszawa 1996, 22-39, 74-77; David Irving, Goebbels mózg Trzeciej Rzeszy [Goebbels the brain of the Third Reich], translated by Bartłomiej Zborski, Gdynia 1998, 28-46, 89-92.

28 Chazbijewicz, "Jakub Szynkiewicz”, 10. 
Goebbels, his colleague from the student days, directly and impel him to issue an order to conduct racial studies on the Lithuanian Karaites. The studies were supposed to prove that they belonged to the Altay people, from whom Turks and Tatars derive. That was supposed to save the Karaites from annihilation and at the same time many Jews who pretended to be Karaites. Based on that, the mufti was to issue certificates for those Jews stating that they were Muslim, and that is why, they had been circumcised. However, as already stated, Chazbijewicz does not offer any evidence for the close relationship between Szynkiewicz and Goebbels or any confirmation of the fact that the former saved Karaites. ${ }^{29}$ Unfortunately, many other authors of works about J. Szynkiewicz's activities during the Second World War tend to duplicate the content included in S. Chazbijewcz's articles and books without any attempt at verifying it. ${ }^{30}$

Meanwhile, it is not true that the Lithuanian Karaites were in danger of extermination in 1943. On 1 September 1941, German Commissioner-General of Lithuania (Generalkommissar Litauen) Theodor Adrian von Renteln issued a directive confirming that the local Karaites' status was different from the Jewish one, probably on the basis of studies conducted by numerous scientists of different nationalities (including Italian Professor Corado Gini) in the 1930s. Undoubtedly, this document freed this community from destruction faced by the Jews in the same area. First and foremost, it was Khan Seraya Shapshal who contributed to saving the Karaites as he was accepted as the leader of the Lithuanian Karaites by the new authorities, which was taken away from him under the Soviet occupation. In order to protect his fellow believers, he met with the German officials to persuade them of the non-Jewish origin of the Karaites. Nonetheless, even after 1941, various German institutions continued to be interested in the origin, the history and the culture of the Karaites. Thus, for instance, in the letter of 25 November 1942, Institut für Grenz- und Auslandstudien in Berlin demanded all materials regarding Karaites from S. Shapshal. In December 1942, the members of the community were exhaustively examined by German doctors together with Muslims surely for their race. ${ }^{31}$

The diary by Professor Szymon Pilecki, acting President of the Karaite Religious Association in Poland, includes interesting pieces of information regarding the issue under discussion. Under the date of 5 September 1942, he wrote that he attended a meeting about the Tatars leaving

29 Selim Chazbijewicz, Azja w środku Europy. Tatarzy w twórczości Józefa Mackiewicza [Asia in the middle of Europe. Tatars in the works of Józef Mackiewicz], ,Tytuł. Pismo literacko-artystyczne [Title. Literary and artistic magazine]", (1995) issue no. 1, 42-49; Chazbijewicz, "Tatarzy polsko-litewscy w latach II wojny światowej [Polish-Lithuanian Tatars during World War II], [in:] Meandry cywilizacyjne, kwestie narodowościowe i polonijne [Meanders of civilization, national and Polish diaspora issues], ed. Andrzej Chodubski, $2^{\text {nd }}$ edition, Torun 1998, 97; Chazbijewicz, Tatarzy krymscy. Walka o naród i wolna ojczyznę [Crimean Tatars. Fight for the nation and a free homeland], Poznań-Września 2001, 77; Chazbijewicz, “Jakub Szynkiewicz”, 11.

30 Jan Tyszkiewicz, Z historii Tatarów polskich 1794-1944. Zbiór szkiców z aneksami źródłowymi [From the history of Polish Tatars 1794-1944. A collection of sketches with source annexes], Pułtusk 1998, 147-148; Edward Tryjarski, "Coming to the Rescue of the Karaims during the Second World War, ,Rocznik Orientalistyczny”, 56 (2003), fascicle no. 2, 97-108.

31 The Library of the Lithuanian Academy of Sciences, Manuscripts Catalogue, catalogue no. F. 143-303, leaf no. 2-2v; F. 143-1082, leaf no. 8, 14, 17; Gąsiorowski, "Szapszał Seraja Markowicz (1873-1961)", 62. 
for Crimea, where "a small state or autonomous Tatar district" was supposed to be created. As the Tatars considered "the Karaites one of the three tribes which create the Tatar nationality, they proposed that they" should go with them to Crimea. Sz. Pilecki added that it turned out that a few Karaites also joined the exodus to Crimea in order to avoid being taken away to work in Germany. ${ }^{32}$ Yet, it is unknown what J. Szynkiewicz's influence on these actions was.

The mufti and his family left Wilno with the Germans before 1944. He went to Egypt through Vienna and Rome. He decided to settle there. Famous writer, Józef Mackiewicz described what such a rushed evacuation was like in one of his essays entitled " $Z$ teczki: niefortunne losy" (From the briefcase: unfortunate fate). In 1952, after Gamal Abdel Nasser took over power in Egypt as a result of a coup d'état, J. Szynkiewicz left for the United States of America. He settled permanently near New York where a large community of the Polish Tatars had settled during the interwar period. He died on 1 November 1966 r. in Waterbury, Connecticut. ${ }^{33}$

\section{Conclusions}

J. Szynkiewicz's vibrant and extraordinary life as well as his interesting activities in many fields are certainly worth writing more about, but using all preserved sources in Poland and abroad. He lived in a very difficult time and had to make decisions that were oftentimes crucial and whose motives and effects cannot be judged easily. During the Second World War, J. Szynkiewicz was surely faced with hopeless situations when he was responsible for not only himself and his whole family, but also the Muslim community whose care was entrusted to him. Finally, for Karaitologists, his relations with the Karaite community are of significance, not only during the interwar period, but also during the turbulent years of the Second World War. Yet, in light of available sources, it is impossible to substantiate J. Szynkiewicz's close contact with Joseph Goebbels, and thus his great role in saving the Lithuanian Karaites from annihilation.

Peer-review: Externally peer-reviewed.

Conflict of Interest: The author has no conflict of interest to declare.

Grant Support: The author declared that this study has received no financial support.

Hakem Değerlendirmesi: Dış bağımsız.

Çıkar Çatışması: Yazar çıkar çatışması bildirmemiştir.

Finansal Destek: Yazar bu çalışma için finansal destek almadı̆̆ını beyan etmiştir.

32 Szymon Pilecki, Chłopiec z Leśnik. Dziennik z lat 1939-1945 [Boy from Leśniki. Diary from 1939-1945], [Wrocław] 2009, 233, 235.

33 Józef Mackiewicz, “Z teczki: niefortunne losy [From the briefcase: unfortunate fates]”, [in:] Józef Mackiewicz, Barbara Toporska, Droga pani [Dear lady], London 1984, 328-330; Chazbijewicz, “Jakub Szynkiewicz”, 10-11. 


\section{References/Kaynaklar \\ 1. Primary sources}

Archive of Science PAN\&PAU in Cracow. Zespół Tadeusz Kowalski, catalogue no. K III - 4, 175, leaf no. 3, 6-6v.

The Library of the Lithuanian Academy of Sciences, Manuscripts Catalogue, catalogue no. F. 143-79; no. F. 143-303; F. 143-1082.

Zarządzenie 179. Dziennik Ustaw RP z 24 kwietnia 1936 r. M.P. 1936 nr 97 poz. 179 (Directive no. 179. the Journal of Laws of the Republic of Poland from 24 April 1936 Monitor Polski 1936 item no. 179). March 20. 2021. isap.sejm.gov.pl.

\section{Published sources}

"Euroislam", Dawid Warszawski’s interview with Selim Chazbijewicz, Gazeta Wyborcza, 16 July, 2004. March 20, 2021.www.ipdirect.home.pl/kmp/kiosk/Polscy_muzulmanie/euroislam_selim_chazbijewicz. htm; www.alislam.plwww.alislam.pl.

Firkowicz Szymon, "Przyjazd Reszyd Saffet Beja” [Arrival of Reşit Saffet Bey], Myśl Karaimska, 2 (1931), fascicle no. 3/4, 75-77.

"Kronika" [Chronicle], Ateneum Wileńskie, 10 (1935), 569.

"Kronika" [Chronicle], Rocznik Tatarski, 1 (1932), 321-324.

"Kronika" [Chronicle], Rocznik Tatarski, 2 (1935) 478.

Łopatto Emanuel Włodzimierz, Byle na Zachód [Anywhere to the West], conversations with Wiesław Mincer, Warszawa 2001, 99.

Mackiewicz Józef, “Z teczki: niefortunne losy [From the briefcase: unfortunate fates]”, [in:] Józef Mackiewicz, Barbara Toporska, Droga pani [Dear lady], London 1984, 328-330.

Pilecki Szymon, Chłopiec z Leśnik. Dziennik z lat 1939-1945 [Boy from Leśniki. Diary from 1939-1945], [Wrocław] 2009, 233, 235.

Reviewed by J. Szynkiewicz, Rocznik Tatarski, 2 (1935), 454-455.

Schinkewitsch Jakob, Rabghûzîs Syntax. Inaugural-Dissertation zur Erlangung der Doktorwürde genemigt von der Philosophischen Fakultat der Friedrich-Wilhelm-Universitat zu Berlin. Tag der Promotion: Berlin 10. Juni 1926, 47.

Szynkiewicz Jakób, "Literatura religijna Tatarów litewskich i jej pochodzenie" [Religious literature of Lithuanian Tatars and its origin], Rocznik Tatarski, 2 (1935), 138-145.

Szynkiewicz Jakób, “O kitabie” [About kitaba], Rocznik Tatarski, 1 (1932), 188-194.

Szynkiewicz Jakób, “Tłumaczenia słów i nazw orientalistycznych" [Translations of oriental words and names], [in:] Stanisław Dziadulewicz, Herbarz rodzin tatarskich w Polsce [Herbarium of the Tatar families in Poland], Wilno 1929, 457-473.

"Sprawozdanie muftiego Jakuba Szynkiewicza z podróży do Turcji, Syrii, Palestyny i Egiptu w roku 1932 (9 IV - 9 IX)“ [Report by Mufti Jakub Szynkiewicz on his trips to Turkey, Syria, Palestine and Egypt in 1932], prepared for print by Artur Pałasiewicz, Przeglad Orientalistyczny, (1977) issue no. 1, 41-48.

Sprawozdania z podróży muftiego Jakuba Szynkiewicza. Źródła, omówienie, interpretacja [Reports from the journey of Mufti Jakub Szynkiewicz. Sources, overview, interpretation], prepared by Grzegorz Czerwiński, scholarly editing by Jarosław Ławski and Grzegorz Kowalski, Białystok 2013 Książnica Podlaska in. Łukasza Górnickiego, 323, ill. (Colloquia Orientalia Bialostocensia. Literatura, historia; 5). 
Szapszał Seraja Hadży (Seraya Hajji Shapshal), "O zatraceniu języka ojczystego przez Tatarów w Polsce” [About the loss of the mother tongue by the Tatars in Poland], Rocznik Tatarski, 1 (1932), 34-48.

"Uroczystość wręczenia odznaczeń najwyższym duchownym: karaimskiemu i muzułmańskiemu” [The ceremony of awarding decorations to the highest clergy: Karaim and Muslim], Myśl Karaimska, 11 (1935-1936) fascicle no. 11 [printed:] 1936, 123-125.

"Z życia Karaimów w Polsce” [From the life of Karaims in Poland], Myśl Karaimska, 11 (1935-1936), fascicle no. 11 [printed:] 1936, 114, 117 (photographies).

\section{Secondary sources}

Bohdanowicz Leon, Chazbijewicz Selim, Tyszkiewicz Jan, "Tatarzy muzułmanie w Polsce” [Muslim Tatars in Poland], Gdańsk 1997, 44-45.

Borawski Piotr, "Tatarzy w dawnej Rzeczypospolitej” [Tatars in the former Polish-Lithuanian Commonwealth], Warszawa 1986, 297.

Chazbijewicz Selim, Azja w środku Europy. Tatarzy w twórczości Józefa Mackiewicza [Asia in the middle of Europe. Tatars in the works of Józef Mackiewicz], ,Tytuł. Pismo literacko-artystyczne [Title. Literary and artistic magazine]", (1995) issue no. 1, 42-49.

Chazbijewicz Selim, “Jakub Szynkiewicz postać tragiczna” [Jakub Szynkiewicz a tragic figure], Przegląd Tatarski, (2011) issue no. 2, 8-11.

Chazbijewicz Selim, Tatarzy krymscy. Walka o naród $i$ wolną ojczyznę [Crimean Tatars. Fight for the nation and a free homeland], Poznań-Września 2001, 77.

Chazbijewicz Selim, "Tatarzy polsko-litewscy w latach II wojny światowej [Polish-Lithuanian Tatars during World War II], [in:] Meandry cywilizacyjne, kwestie narodowościowe i polonijne [Meanders of civilization, national and Polish diaspora issues], pod red. Andrzeja Chodubskiego, $2^{\text {nd }}$ edition, Toruń 1998, 97.

Czerwiński Grzegorz, “O „sprawozdaniach” Jakuba Szynkiewicza, czyli Mufti Drugiej Rzeczpospolitej jako pisarz" [About the "reports" of Jakub Szynkiewicz, or the Mufti of the Second Republic as a writer], [in:] Pogranicza, Kresy, Wschód a idee Europy [Borderlands, Kresy, the East and the ideas of Europe]. Seria II: Wiktor Choriew in memoriam, scholarly editing by Anna Janicka, Grzegorz Kowalski and Łukasz Zabielski, Białystok 2013 (Colloquia Orientalia Bialostocensia. Literatura, historia; 4).

Dziekan Marek M., “Szynkiewicz Jakub (1884-1966)”, [in:] Pisarze muzułmańscy VII-XX w. [Muslim writers of the 7th-20th centuries], Warszawa 2003, 112.

Fałowski Janusz, "Uwagi o sytuacji prawnej Karaimskiego Związku Religijnego w II Rzeczypospolitej” [Comments on the legal situation of the Karaim Religious Association in the Second Polish Republic], [in:] Między Wschodem a Zachodem [Between East and West], Piotra Stawińskiego (ed.), Częstochowa 1995, 41-43.

Gąsiorowski Stefan, "Szapszał Seraja Markowicz (1873-1961)”, [in:] Polski Słownik Biograficzny [Polish Biographical Dictionary], Vol. 47, Warszawa-Kraków 2010, fascicle no. 192, 61-64.

Irving David, Goebbels mózg Trzeciej Rzeszy [Goebbels the brain of the Third Reich], translated by Bartłomiej Zborski, Gdynia 1998, 28-46, 89-92.

Januszewska-Jurkiewicz Joanna, Stosunki narodowościowe na Wileńszczyźnie w latach 1920-1939 [National relations in the Vilnius Region in the years 1920-1939], $2^{\text {nd }}$ edition, Katowice 2011, 650.

Kołodziejczyk Arkadiusz, "Komitet Budowy Meczetu w Warszawie" [Mosque Building Committee in Warsaw], Życie Muzutmańskie, 2 (1407/1408; 1987), no. 2-4, 45, 47-49. 
Kryczyński Leon Najman Mirza, "Tatarzy polscy a wschód muzułmański" [Polish Tatars and the Muslim East], Rocznik Tatarski, 2 (1935) 76.

Majchrowski Jacek M., “Osoby kierujące prawnie uznanymi związkami wyznaniowymi” [Persons managing legally recognized religious associations], [in:] Kto byt kim w Drugiej Rzeczypospolitej [Who was who in the Second Polish Republic], scholarly ed. by J. M. Majchrowski, in cooperation with Grzegorz Mazur and Kamil Stepan, Warszawa 1994207

Miśkiewicz Ali, "Mufti na Rzeczpospolitą Polską dr Jakub Szynkiewicz. Notka biograficzna w 20 rocznicę śmierci" [Mufti for the Republic of Poland, Dr. Jakub Szynkiewicz. Biographical note on the 20th anniversary of his death], Życie Muzulmańskie, 1 (1407; 1986) issue no. 1, 11-13.

Rąkowski Grzegorz, Ilustrowany przewodnik po zabytkach kultury na Litwie [Illustrated guide to cultural monuments in Lithuania], Warszawa 1999, 408.

Reuth Ralf Georg, Goebbels, translated by Michał Misiorny, Warszawa 1996, 22-39, 74-77.

Stankiewicz Jan, "Belaruskija musulmanie i belaruskaja literatura arabskim pismom”, Hadawik Belaruskaga nawukowaga tawarystwa u Wilni, 1 (1933), 111-141.

"Szynkiewicz Jakub", [in:] Czy wiesz kto to jest? [Do you know who it is?] [Vol.] 2: Uzupetnienia i sprostowania. Przedruk [Additions and corrections. Reprint], Stanisław Łoza (ed.), Warszawa 1983, 309.

Tryjarski Edward, “Coming to the Rescue of the Karaims during the Second World War, „Rocznik Orientalistyczny”, 56 (2003) fascicle no. 2, 97-108.

Tyszkiewicz Jan, “Olgierd, Leon i Stanisław Kryczyńscy, działacze kulturalni i badacze przeszłości Tatarów” [Olgierd, Leon and Stanisław Kryczyński, cultural activists and researchers of the Tatars' past], [in:] Leon Najman Mirza Kryczyński lider ruchu spolecznego i kulturalnego Tatarów Polskich [Leon Najman Mirza Kryczyński leader of the social and cultural movement of the Polish Tatars], Selim Chazbijewicz (ed.), Gdańsk-Gdynia 1998, 23.

Tyszkiewicz Jan, Z historii Tatarów polskich 1794-1944. Zbiór szkiców z aneksami źródtowymi [From the history of Polish Tatars 1794-1944. A collection of sketches with source annexes], Pułtusk 1998, 147-148. 
